\title{
On the influence of crack closure on strength estimates of wood
}

\author{
Nielsen, Lauge Fuglsang
}

Published in:

European Journal of Wood and Wood Industries (Print)

Link to article, DOI:

$10.1007 /$ s00107-003-0446-x

Publication date:

2004

Document Version

Publisher's PDF, also known as Version of record

Link back to DTU Orbit

Citation (APA):

Nielsen, L. F. (2004). On the influence of crack closure on strength estimates of wood. European Journal of Wood and Wood Industries (Print), 62, 81-87. https://doi.org/10.1007/s00107-003-0446-x

\section{General rights}

Copyright and moral rights for the publications made accessible in the public portal are retained by the authors and/or other copyright owners and it is a condition of accessing publications that users recognise and abide by the legal requirements associated with these rights.

- Users may download and print one copy of any publication from the public portal for the purpose of private study or research.

- You may not further distribute the material or use it for any profit-making activity or commercial gain

- You may freely distribute the URL identifying the publication in the public portal

If you believe that this document breaches copyright please contact us providing details, and we will remove access to the work immediately and investigate your claim 


\section{F. Nielsen}

\section{On the influence of crack closure on strength estimates of wood}

Published online: 6 February 2004

(C) Springer-Verlag 2004

\begin{abstract}
Three well-known duration of load models (Gerhard, Barrett/Foschi, DVM) are considered in this note with respect to their ability to predict lifetime of wood subjected to harmonically varying loads. The result obtained is that they practically predict the same lifetime-which for low frequency loading can be considered approximately true. For higher frequencies, however, this result can be far too overestimated. The reason is that the models considered do not take into account the effect of the crack closure phenomenon (which are the main mechanisms of energy dissipation causing fatigue failure in metals).

It is suggested that any of the simple models can be used in practice when low frequency load variations are considered. The DVM model, however, should be preferred because of its ability to predict residual strength, and because of its 'build in' flexibility with respect to wood quality and ambient climatic conditions.

For high frequency load histories more refined models are required. The extended DVM model, recently developed by the author, is suggested as such a modelespecially because it has the potentials of being further developed to consider arbitrary load variations (such as earthquakes).

Finally, the widely spread concept of estimating longterm strength by multiplying short time strength with a codified factor (so-called $k_{M O D}$ factor) is discussed. It is concluded that the $k_{M O D}$-method can be justified in practice with low frequency load variations. When high frequency load histories or unexpected peak loads are considered, the $k_{M O D}$-method may cause considerably overestimated lifetimes.
\end{abstract}

\section{Der Einfluss des Riss-Schließ-Phänomens bei Festigkeitsschätzungen von Holz}

Zusammenfassung Drei bekannte Belastungsdauermodelle werden in dieser Arbeit im Bezug auf ihre Fähigkeit, die Standzeiten von Holz, welches harmonisch wechselnden Lasten ausgesetzt wird, vorauszusagen. Das Ergebnis ist, dass sie beinahe identische Lebenserwartungen voraussagen, was für Belastungen mit niedrigen Wechselfrequenzen als gültig angesehen werden kann. Bei höheren Frequenzen können die Ergebnisse allerdings zu hoch geschätzt sein. Der Grund hierfür liegt darin, dass die herangezogenen Modelle das Riss-Schließ-Phänomen unberücksichtigt lassen (welches auch der Hauptmechanismus für Energiezerstreuung ist und in Metallen zu Materialermüdung führt). Es wird vorgeschlagen, dass jedes dieser einfachen Modelle in der Praxis verwendet werden kann, wenn Variationen von Belastungen mit niedrigen Wechselfrequenzen betrachtet werden. Dem DVM Modell ist allerdings der Vorzug zu geben, da es Restfestigkeit voraussehen kann und flexibel im Bezug auf Holzqualität und klimatische Umgebung ist. Für Belastungen mit hoher Wechselfrequenz werden komplexere Modelle benötigt. Das erweiterte DVM Modell, kürzlich vom Author entwickelt, wird als solches Modell vorgeschlagen, besonders, da es weiterentwickelt werden kann, um willkürliche Belastungschwankungen (wie etwa Erdbeben) mit einzubeziehen. Abschließend wird die gängige Praxis, Langzeitfestigkeit dadurch zu berechnen, indem man die Kurzzeitfestigkeit mit einem festgelegten Faktor (dem sog. $k_{M O D}$ Faktor) multipliziert, besprochen. Diese Praxis ist laut den Ergebnissen bei Variationen von Belastungen mit niedriger Wechselfrequenz anwendbar. Bei höheren Frequenzen kann diese Methode allerdings zu erheblich überschätzten Lebensdauern führen.

\section{Notations}

Load and strength Theoretical strength (no damage): $\sigma_{l} \cdot$ Real strength at $t=0: \sigma_{C R} \cdot$ Strength level (wood quality): $F L=\sigma_{C R} / \sigma_{l} \cdot$ Load: $\sigma \cdot$ Load level: $S L=\sigma / \sigma_{C R}$.
L. F. Nielsen (

Civil Engineering Department,

Technical University of Denmark,

Building 118, 2800 Lyngby, Denmark

e-mail: lfn@byg.dtu.dk 
Max load: $\sigma_{M A X} \cdot$ Min load: $\sigma_{M I N} \cdot$ Load ratio: $p=\sigma_{M I N} / \sigma_{M A X} \cdot$ Cyclic time: $T \cdot$ Frequency: $f=1 / T$. Fractional time under max load: $\beta$. Real strength at $t$ : $\sigma_{C R}(t) \cdot$ Residual strength: $S_{R}=\sigma_{C R}(t) / \sigma_{C R}$

Damage Initial crack length: $l_{0} \cdot$ Immediate crack length: $l \cdot$ Damage ratio (or just damage): $\kappa=l / l_{o} \cdot$ Fatigue parameters in extended DVM model: C, $M$. Damage degree in the models of Gerhard's and Barrett/Foschi's: $\alpha$. Fit parameters in Gerhard's model: A,B - Fit parameters in Barrett/Foschi: C,D,E,F

Time and creep Time in general: $t$. Creep function: $c=\left[1+(t / \tau)^{b}\right] / E \cdot$ Young's modulus: $E \cdot$ Relaxation time in creep: $\tau$ - Creep power: $b$. Time shift parameter: $q=(0.5(1+b)(2+b))^{1 / b}$

\section{Introduction}

Three lifetime models for wood are currently discussed ${ }^{1}$ with respect to their ability to act as a duration of load basis in 'Reliability-based design of timber structures': The theory of Gerhard's (Gerhard 1979), the theory of Barrett/Foschi (1978a, b), and the theory of Fuglsang's (Nielsen 1982, 1991; Madsen 1992), the so-called DVM theory (Damaged Viscoelastic Material).

Basically, all three models are developed for constant loads. The DVM model, however, is prepared also to consider some continuous load variations. In spite of any restrictions on the three models-but because of their simplicity, there is a demand from the wood community for using one of them as a basis for 'rules' in design of wood structures subjected to variable loads.

On this background the three models are compared in this note with respect to their ability to predict lifetime of wood subjected to harmonically varying block loads as defined in Fig. 2. The predictions obtained are evaluated against 'experimental data' represented by an extended version of the DVM theory (Nielsen 1993, 2000) which has proven its ability to describe very well measured lifetime ('real experimental data') of wood subjected to load histories similar to the kind just defined.

\subsection{Model presentation}

The basic expressions of the three theories mentioned above are the following:

$$
\begin{aligned}
& \frac{d \alpha}{d t}=\frac{1}{A} * \exp (B * S L) \\
& (A, B)=\left(1.58 * 10^{14}\right. \text { hours, 36.2) }
\end{aligned}
$$

\footnotetext{
${ }^{1}$ For example in the European Commission COST-E24 project where preliminary studies are made with respect to code preparation for reliability based design of timber structures.
}

$\frac{d \alpha}{d t}=C *(S L-F)^{D}+E * \alpha$

Barrett/Foschi

$(C, D, E, F)=\left(10 /\right.$ hour, $25,10^{-8.5} /$ hour, 0$)$

$\frac{d \kappa}{d t}=\frac{(\pi F L)^{2}}{8 q \tau} \frac{\kappa S L^{2}}{\left(1 /\left(\kappa S L^{2}\right)-1\right)^{1 / b}} ;$

$q=(0.5(1+b)(2+b))^{1 / b} \quad$ Simple DVM

$(F L, b, \tau)=(0.3,0.2,10$ days $)$

Basically the theories of Gerhard's and Barrett/ Foschi's are empirical where the parameters $A-F$ have to be determined by calibration to experimental data. The so-called degree of damage $\alpha$ develops from 0 at loading time $(t=0)$ to 1 at time $\left(t_{C A T}\right)$ where catastrophic failure occurs. $S L$ is load level as defined in the list of notations.

The DVM theory is based on a crack mechanical analysis of wood. The damage ratio $\kappa$, defined in the list of notations, develops from 1 at start of loading to $1 / S L^{2}$ at failure, where the rate of the damage ratio becomes infinitely high. $F L$ is wood quality as defined in the list of notations. The relaxation time, $\tau$, and the creep power, $b$, define the creep experienced by the wood in damage areas (see Fig. 1 and list of notations). Equation 3 is subsequently referred to as the simple DVM theory. The other version of the DVM theory previously mentioned (Nielsen 1993, 2000) will be referred to by the adjectives 'extended' or 'generalized'.

Remark. Contrary to Eqs. 1, 2 and 3, the extended DVM theory operates with two dissipative mechanisms being responsible for the duration of load effects in wood: One is the creep mechanism (already taken care of in Eq. 3). The other one is the so-called crack closure mechanism well known from fatigue studies of metals. The generalized theory applies for any damaged viscoelastic material (with Power law creep). As special cases metals are included with no creep, $\tau=\infty$.

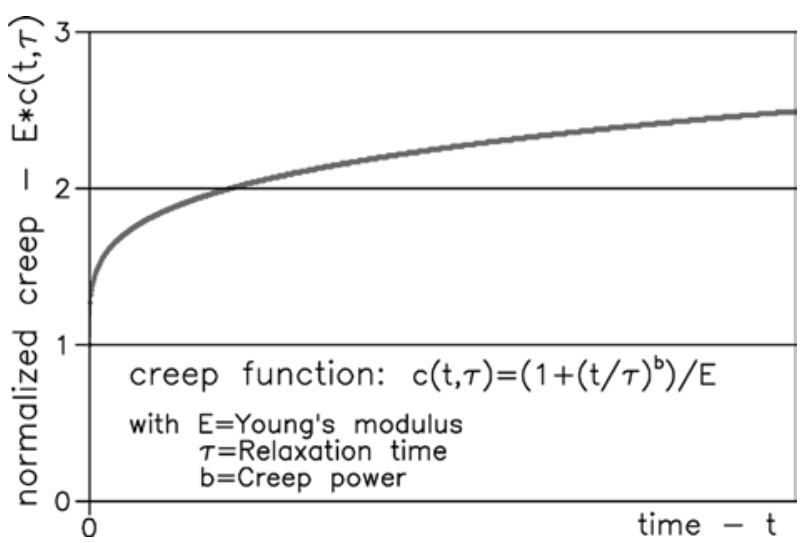

Fig. 1 Creep function for materials with so-called Power-law creep Abb. 1 Kriechfunktion für Materialien, deren Kriechen nach dem sog. Potenzgesetz verläuft 


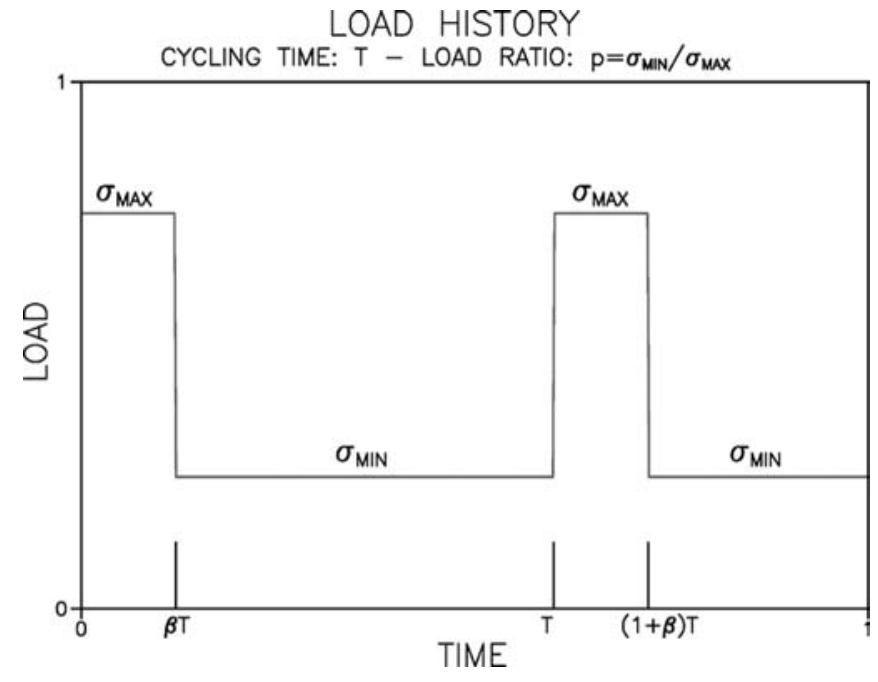

Fig. 2 Basic load variation considered: Square wave loading. $\sigma_{M I N}=p^{*} \sigma_{M A X}$. In present analysis: $\beta=0.5$

Abb. 2 Grundlegende Lastvariation nach einer Rechteck-Funktion: $\sigma_{M I N}=p^{*} \sigma_{M A X}$. Im vorliegenden Fall: $\beta=0,5$

\section{Preparation of analysis}

In the following the Gerhard's, the Barrett/Foschi's, and the simple DVM model will be analyzed with respect to their ability to describe duration of load effects for variable loading as defined in Fig. 2 with fractional time under max load, $\beta=0.5$.

As previously mentioned the 'experimental' data used in the evaluation process will be simulated by the extended DVM theory. To get a common basis in the analysis we calibrate all three theories to the BM-trend line established by Borg Madsen in (Madsen 1992, Fig. 6.1) for the lifetime $\left(t_{C A T}\right)$ of clear wood specimens subjected to long term loading,

$t_{C A T}=1.58 * 10^{14} * 10^{-15.7 * S L}$ hours $\mathrm{BM}-$ trend

The fit parameters $(A-F)$ in Eqs. 1 and 2 and the material parameters $(F L, b, \tau)$ in Eq. 3 have the order of magnitudes indicated. The Gerhard fit is exact. The calibration quality of the Barrett/Foschi expression can be studied in Fig. 3, (in the present context the Barrett/Foschi is fitted sufficiently well introducing $F=0$ ). The DVM theory is calibrated to the BM-trendline data using a computer program reported in (Nielsen 2003). The results are $(F L, b, \tau)=(0.3,0.2,10$ days $)$ which are within the range of reliable OM-estimates (order of magnitudes) declared in (Nielsen 2000). The calibration quality can be studied in Fig. 4.

The fatigue parameters, $C$ and $M$, appearing in the extended DVM theory are chosen by their average quantities presented in (Nielsen 2000), namely $C, M=3,9$, (the parameters $F L, b, \tau$ keep their quantities from Eq. 3).

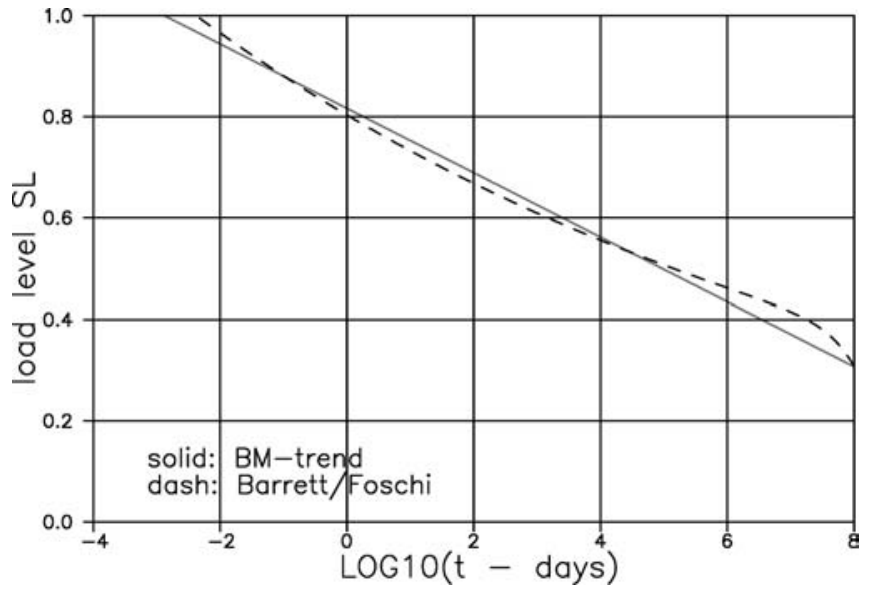

Fig. 3 Calibration of Barrett/Foschi to the BM-trend: $t_{C A T}($ days $)=6.58 * 10^{12 *} 10^{-15.7 S L}$

Abb. 3 Anpassung des Barrett/Foschi- an den BM-Trend: $t_{C A T}($ Tage $)=6,58 * 10^{12 *} 10^{-15,7 S L}$

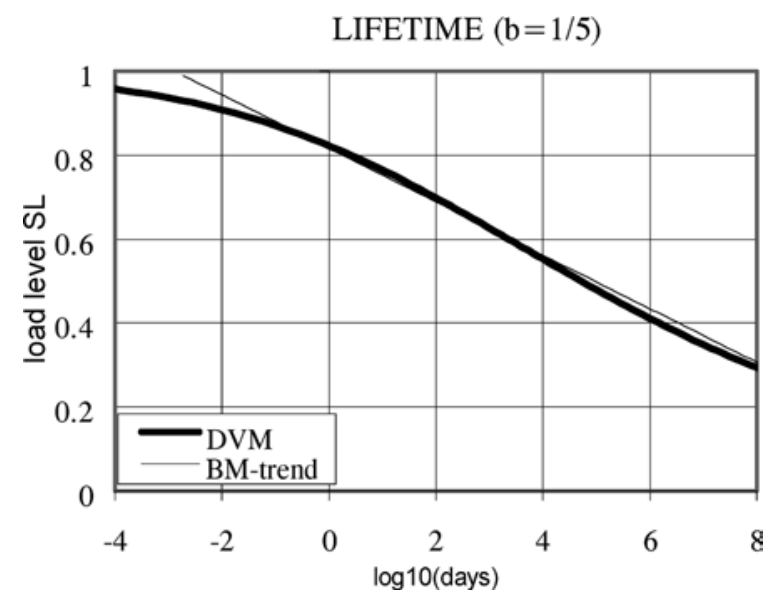

Fig. 4 Calibration of DVM to the BM-trend: $t_{C A T}($ days $)=6.58 * 10^{12} * 10^{-15.7 S L}$

Abb. 4 Anpassung des DVM- an den BM-Trend: $t_{C A T}($ Tage $)=6,58 * 10^{12 *} * 10^{-15,7 S L}$

\section{Analysis}

Some results of an evaluation of the three theories considered will now be demonstrated. (Similar results have previously been presented in (Nielsen 1997, 2001a, 2001b, 2002a, 2002b). The results are arranged such that the three methods (Eqs. 1, 2 and 3) are mutually compared in Figs. 5, 7, and 9.

In Figs. 6, 8, and 10 the methods are evaluated against 'experimental data' as simulated by the extended DVM theory.

We notice that lifetime predictions by the DVM theories include predictions of 'residual strength' (defined as 'strength left' or 're-cycle strength). The Gerhard and Barrett/Foschi theories cannot describe this property. 


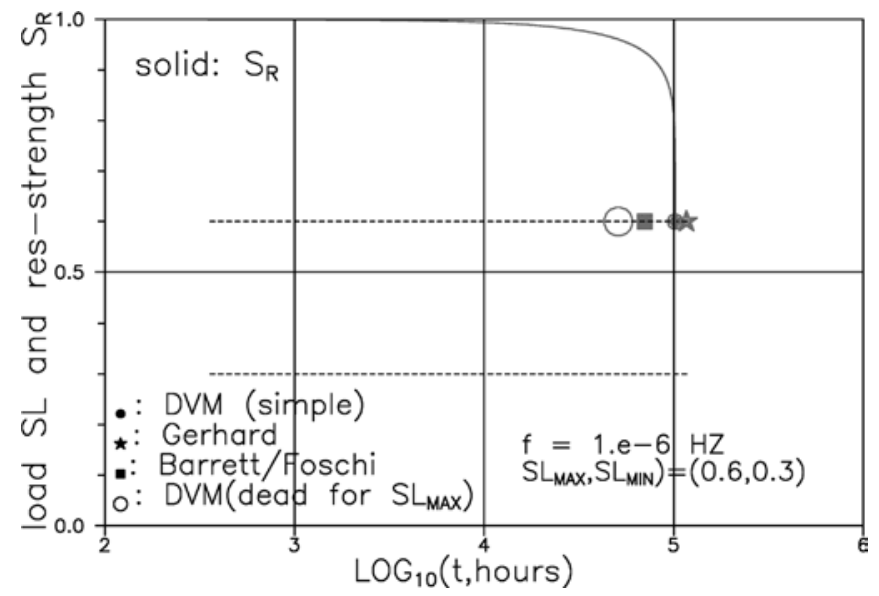

Fig. 5 Prediction of lifetime using Eqs. 1, 2, 3 (simple DVM theory). Crack closure not considered

Abb. 5 Vorhersage der Standzeit mittels Gl. 1, 2, 3 (einfache DVM-Theorie). Rissschluss ist nicht berücksichtigt

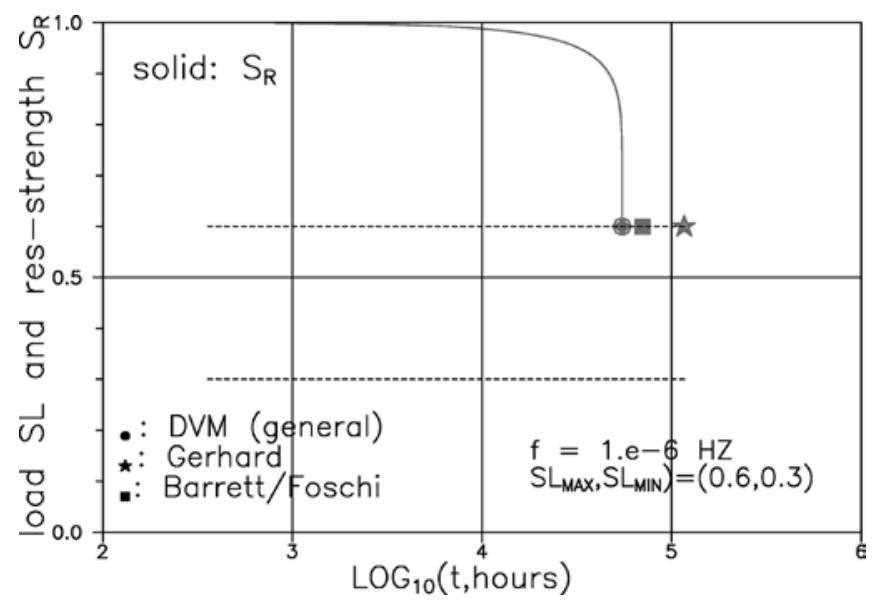

Fig. 6 Prediction of lifetime using Eqs. 1, 2 and the extended DVM theory with crack closure considered

Abb. 6 Vorhersage der Standzeit mittels Gl. 1, 2 und der erweiterten DVM-Theorie mit Berücksichtigung des Rissschlusses

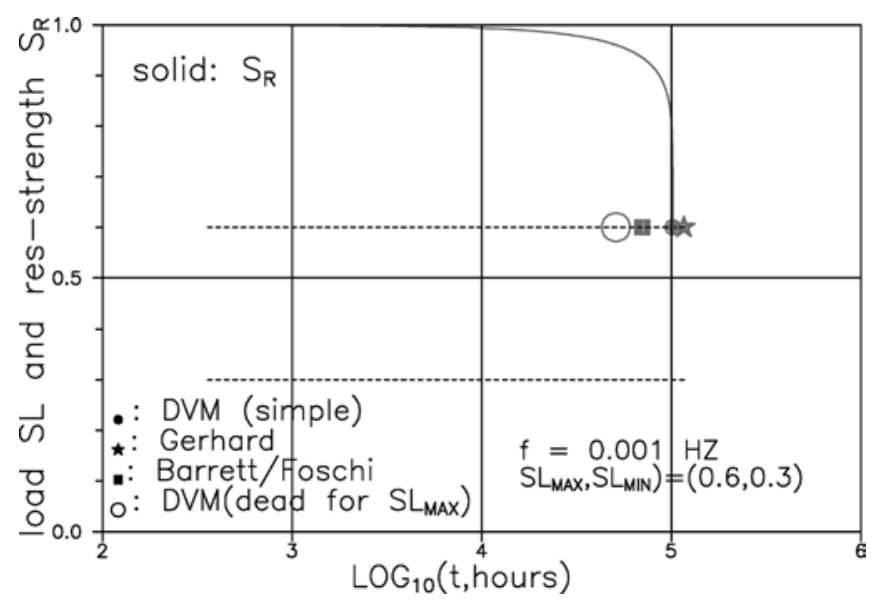

Fig. 7 Prediction of lifetime using Eqs. 1, 2, 3 (simple DVM theory). Crack closure not considered

Abb. 7 Vorhersage der Standzeit mittels Gl. 1, 2, 3 (einfache DVM-Theorie). Rissschluß ist nicht berücksichtigt

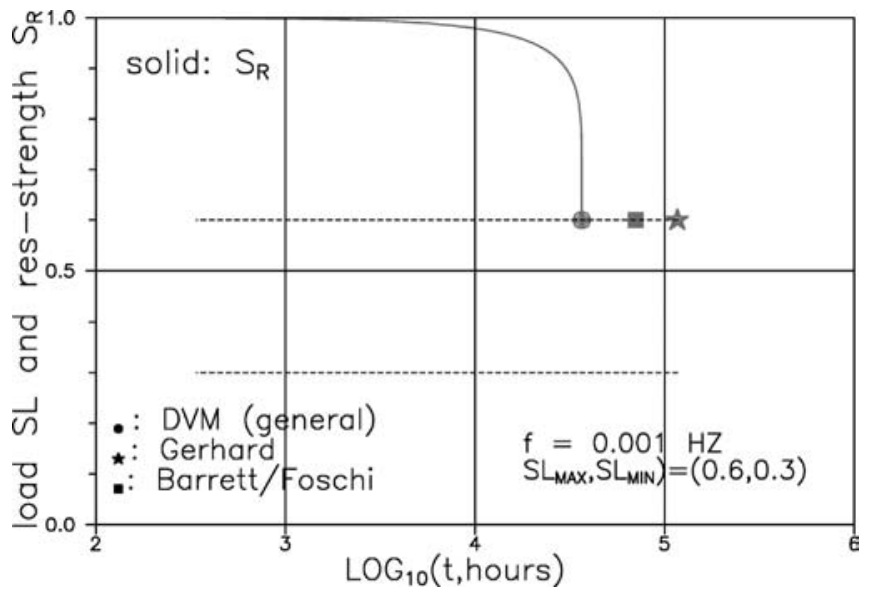

Fig. 8 Prediction of lifetime using Eqs. 1, 2 and the extended DVM theory with crack closure considered

Abb. 8 Vorhersage der Standzeit mittels Gl. 1, 2 und der erweiterten DVM-Theorie mit Berücksichtigung des Rissschlusses

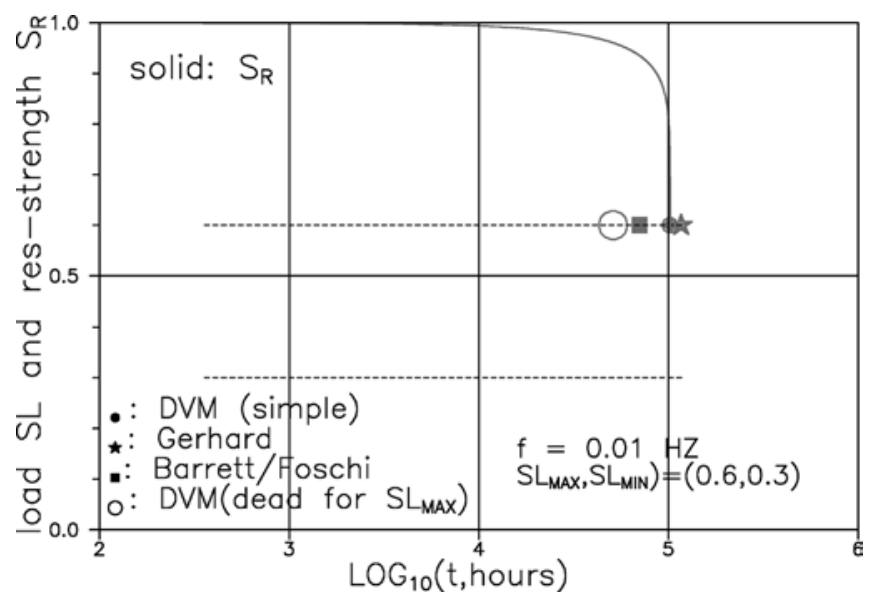

Fig. 9 Prediction of lifetime using Eqs. 1, 2, 3 (simple DVM theory). Crack closure not considered

Abb. 9 Vorhersage der Standzeit mittels Gl. 1, 2, 3 (einfache DVM-Theorie). Rissschluss ist nicht berücksichtigt

\section{Intermediate conclusions and remarks}

The empirical Gerhard's and Barrett/Foschi's models do not consider the crack closure phenomenon as a driving mechanism in damage propagation. The simple DVM model also disregards this mechanism. These three models are compared in Figs. 5, 7, and 9. It is seen that they practically predict the same lifetime independently of load frequencies - a behavior which has clearly been demonstrated, not to be true by Bach (1979) already in 1975. The observation of Bach's has later been confirmed by a number of other authors (e.g. Clorius 2001).

Theoretically the observation of Bach's is in accordance with the results of the extended version of the DVM theory (Nielsen 2000) developed for lifetime studies of damaged viscoelastic materials in general.

The Gerhard's and Barrett/Foschi's models (and indirectly also the simple DVM model) are compared with the 


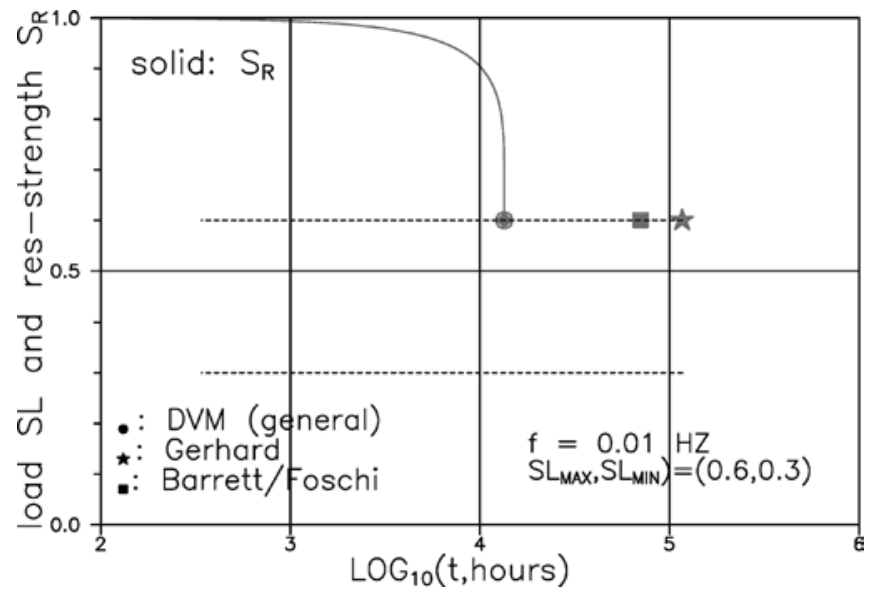

Fig. 10 Prediction of lifetime using Eqs. 1, 2 and the extended DVM theory with crack closure considered

Abb. 10 Vorhersage der Standzeit mittels Gl. 1, 2, 3 und der erweiterten DVM-Theorie mit Berücksichtigung des Rissschlusses

\section{HOURS TO FAILURE - tCAT (read lower graphs)}

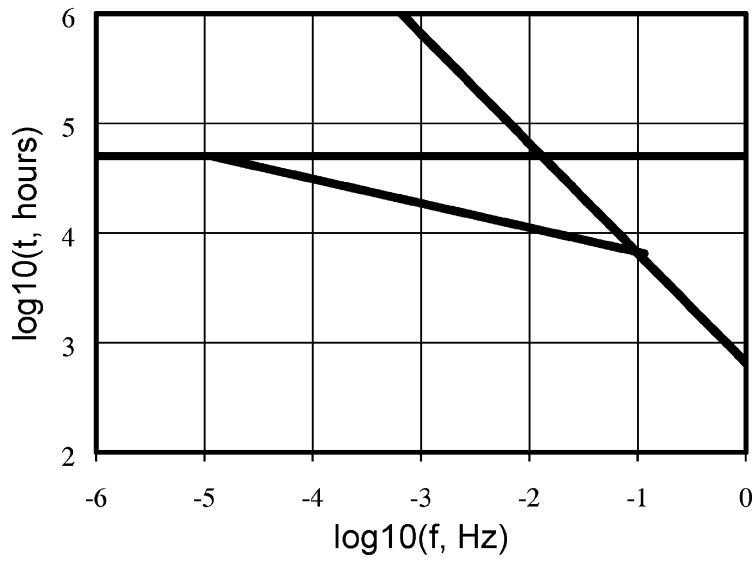

Fig. 11 Safe lifetime estimates of wood with properties and a load history as considered in this paper: $(F L, b, C, M)=(0.3,0.2,3,9)$ and $\left(S L_{M A X}, p\right)=(0.6,0.5)$

Abb. 11 Schätzen der sicheren Standzeit für Holz mit Eigenschaften und einer Belastungsgeschichte, wie sie hier betrachtet werden: $(F L, b, C, M)=(0,3,0,2,3,9)$ and $\left(S L_{M A X}, p\right)=(0,6,0,5)$

'experimental data' in Figs. 6, 8, and 10. It is observed that all data sets practically coincide at low load frequencies. Apparently the energy dissipation caused by creep overrides the dissipation caused by crack closure mechanisms.

This conclusion, however, cannot be maintained when rapid load variations are considered (Fig. 10). Lifetime is considerably overestimated when using the Gerhard's, the Barrett/Foschi's, and the simple DVM theories on rapidly varying load situations. Apparently the energy dissipation caused by crack closure mechanisms overrides the dissipation caused by creep mechanisms.

Remark. The observations just made are clearly demonstrated in Figs. 11 and 12 obtained by a software
HOURS TO FAILURE - tCAT

(read lower graphs)

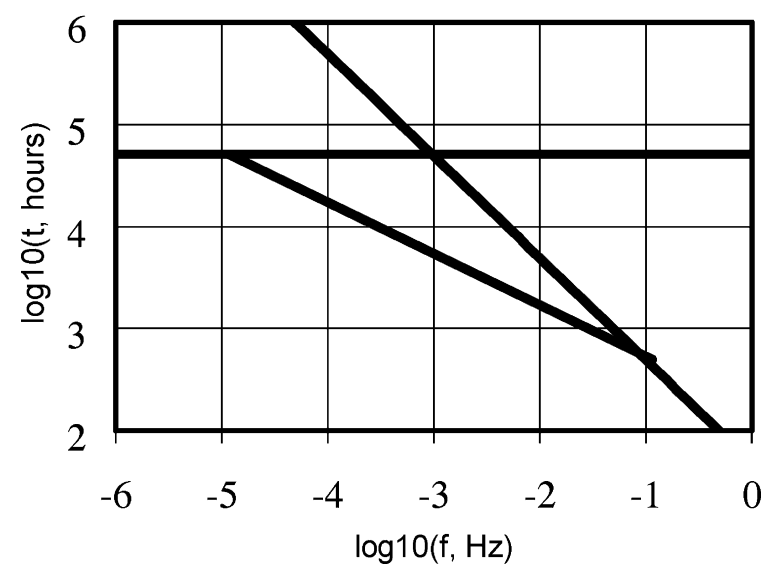

Fig. 12 Safe lifetime estimates of wood with properties as considered in this paper: $(F L, b, C, M)=(0.3,0.2,3,9)$. Loading is $(S L M A X, p)=(0.6,0.001)$

Abb. 12 Schätzen der sicheren Standzeit für Holz mit Eigenschaften und einer Belastungsgeschichte, wie sie hier betrachtet werden: $(F L, b, C, M)=(0,3,0,2,3,9)$ and $\left(S L_{M A X}, p\right)=(0,6,0,001)$

presented in (Nielsen 2003) for easy safe lifetime estimations for wood subjected to the type of load histories considered in this paper. (The horizontal line in the figures is dead load lifetime for wood loaded with $\sigma_{M A X}$. The steepest line in the figures is fatigue lifetime for wood with damage propagation totally dominated by crack closure mechanisms). Both figures refer to the wood properties considered in this paper. The load parameters in Fig. 11 are also the same as previously considered. In Fig. 12, however, the load ratio has been decreased to $p=0$ practically (complete unloading).

The transition range of frequencies between 'low' and 'high' frequency loading is suggested in (Nielsen 2000) to be $10<f^{*} \tau<10^{5}$, which for the wood properties considered in this note means $10^{-5}<f<0.1$.

\subsection{Future}

Harmonic load variations have been assumed in this note. An important future research project is to develop a lifetime theory, which applies for more general variations (non-harmonic load histories). It has been demonstrated in (Nielsen 1996a, 1996b) that the extended DVM theory has the basic potentials to be further generalized for such loads. Figures 13 and 14 demonstrate some results obtained by a pilot theory in (Nielsen 1996a) being tested predicting the residual strength of wood subjected to a simulated load history caused by earthquakes.

\section{Final conclusions}

It seems that any of the simple duration of load models (Eqs. 1, 2 and 3) can be used in practice when low 


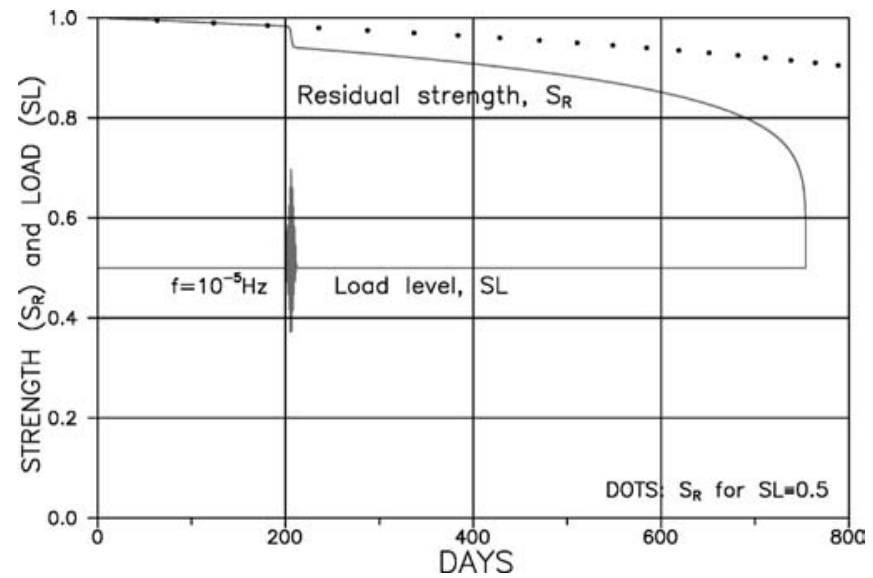

Fig. 13 Lifetime and residual strength of wood, $(F L, b, \tau)=$ $(0.4,0.25,1$ day), loaded with $S L=0.5+1 . e-5 \mathrm{~Hz}$ pulse load at $t \approx 206$ days. The dots indicate residual strength if pulse load is absent

Abb. 13 Standzeit und Restfestigkeit von Holz, $(F L, b, \tau)=(0,4$, 0,25, $1 \mathrm{Tag}$ ), nach Belastung mit $S L=0,5+1 . \mathrm{e}-5 \mathrm{~Hz}$ Puls-Belastung bei $\mathrm{t} \approx 206$ Tage. Die Punkte bezeichnen die Restfestigkeit ohne Puls-Belastung

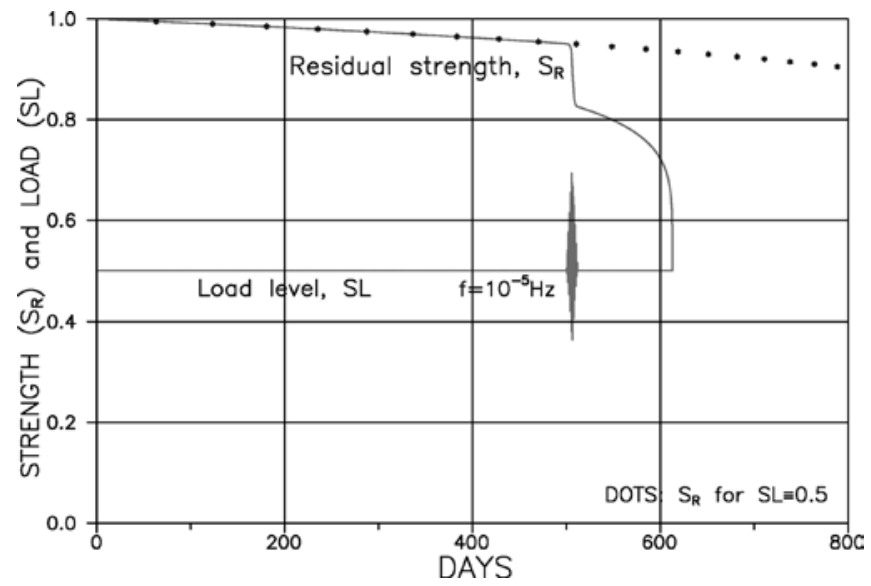

Fig. 14 Lifetime and residual strength of wood, $(F L, b, \tau)=(0.4$, $0.25,1$ day), loaded with $S L=0.5+1 . e-5 \mathrm{~Hz}$ pulse load at $t \approx 506$ days. The dots indicate residual strength if pulse load is absent

Abb. 14 Standzeit und Restfestigkeit von Holz, $(F L, b, \tau)=(0,4$, 0,25, 1 Tag), nach Belastung mit $S L=0,5+1 . e-5$ Hz Puls-Belastung bei $t \approx 506$ Tage. Die Punkte bezeichnen die Restfestigkeit ohne Puls-Belastung

frequency load variations are considered. The DVM model, however, should be preferred because of its ability to predict residual strength, and because of its 'build in' flexibility with respect to wood quality and ambient climatic conditions.

For high frequency load histories, more refined models are required. The extended DVM model, recently developed by the author, is suggested as such a modelespecially because it has the potentials of being further developed to consider arbitrary load variations (such as earthquakes). As a curiosum is noticed that lifetime predicted by the extended DVM model at a very high frequency loading approaches the solution, which can be predicted by a plain fatigue theory (see Figs. 11 and 12).

Finally, the widely spread concept (e.g. Svensson et al. 1999) of estimating long-term strength by multiplying short time strength with a so-called $k_{M O D}$-factor should be related to the findings in this research note:

In principles $k_{M O D}$ factors are calculated using a damage model (disregarding its original constant load assumptions) with forecasted time dependent on load histories (or load levels, $S L$ ). Hitherto, as in (Stang et al. 2002), the determinations of $k_{M O D}$ factors have been based exclusively on the Gerhard's or on the Barrett/Foschi's models. Recently, however, the simple DVM-model (Eq. 3) has also been considered by Köhler, Faber, and Svensson (Köhler 2002, Köhler and Faber 2002, Köhler and Svensson 2002) ${ }^{2}$ in their analysis of the influence on $k_{M O D}$ of the damage model chosen. The conclusion made by these authors is that all three models, when properly calibrated, practically imply the same $k_{M O D}$. This conclusion agrees with the intermediate conclusion previously made in this paper for lifetime predictions with models that disregard crack closure (see Figs. 5, 7 and 9).

Based on the results obtained in this paper, the following conclusion can now be made with respect to the $k_{M O D}$ method: The $k_{M O D}$-method can be justified in practice with low frequency load variations $\left(f^{*} \tau<10\right)$. When higher frequency load histories or unexpected peak loads are considered, the $k_{M O D}$-method may cause considerably overestimated lifetimes.

\section{Literature}

Bach L (1979) Frequency-dependent fracture under pulsating loading". Build. Mat. Lab., Tech. Univ. Denmark, Tech. report 68 (1979), (also presented at Forest Prod. Res. Society Annual Meeting 1975, Portland, Oregon, USA)

Barrett JD, Foschi RO (1978a) Duration of load and probability of failure in wood. Part I: modelling creep rupture. Canadian J Civil Eng 4:505-514

Barrett JD, Foschi RO. (1978b) Duration of load and probability of failure in wood. Part II: constant, ramp, and cyclic loadings. Canadian J Civil Eng 4:515-532

Clorius CO (2001) Fatigue in wood - an investigation in tension perpendicular to grain. PhD Thesis, Department of Civil Engineering, Technical University of Denmark

Gerhards CC (1979) Time-related effects on wood strength: a linear cumulative damage theory. Wood Sci 3:139-144

Köhler J (2002) Probalistic modelling of duration of load effects in timber structures. In: Proceedings of the 4th International PH.D Symposium in Civil Engineering, Technical University of Munich, 19 September 2002, vol.1, pp 317-325

Köhler J, Faber MH (2002) Probalistic modelling of duration of load effects in timber structures. In: Workshop of the COST action E24 'Reliability in Timber Structures', ETH Zurich, Switzerland, October 10-11

Köhler J, Svensson S (2002) Probalistic modelling of duration of load effects in timber structures. In: Proc 35th meeting of CIBW18, Kyoto, Japan, 16-19 September (in press)

${ }^{2}$ The ability of Eq. 3 to consider some continuously varying loads, is utilized in these references. 
Madsen B (1992) Structural behaviour of timber. Timber Engineering Ltd., North Vancouver, B.C, Canada

Nielsen LF (1982) Lifetime analysis of cracked linear viscoelastic materials-with special reference to wood. In: IUFRO Engineering Group Conference, Borås, Sweden, Proceedings: Chalmers Univ. of Technology, Dept. Civ. Eng., Gothenburg, pp 151-178

Nielsen LF (1991) Lifetime, residual strength, and quality of wood and other viscoelastic building materials. Holz Roh- Werkstoff 49:451-455

Nielsen LF (1993) Traes udmattelse-prediktion af traebjaelkers levetid og resstyrke (Fatigue of wood-prediction of lifetime and residual strength). Report LBM-294 (1993), Building Materials Lab., Tech, Univ. Denmark

Nielsen LF (1996a) Lifetime and residual strength of woodsubjected to static and variable load. Report R-6 (1996), Dept. Struct. Eng. and Materials, Tech. University of Denmark

Nielsen LF (1996b) Traethed og reststyrke i beton og andre viskoelastiske materialer med aeldning (Fatigue and residual strength of concrete and other aging viscoelastic materials). Report R-7(1996), Dept. Struct. Eng. and Materials, Tech. University of Denmark

Nielsen LF (1997) Analysis of lifetime and residual strength of wood-Numerical methods for structural analysis. In: Proceedings CTBA-Seminar on 'Reliability based design of timber structures', Paris, 2-3 October 1997, CTBA-Paris

Nielsen LF (2000) Lifetime and residual strength of wood subjected to static and variable load. Part I: introduction and analysis, and
Part II: applications and design. Holz Roh- Werkstoff 58:8190,141-152

Nielsen LF (2001a) Lifetime and residual strength of wood subjected to static and variable load. Contribution to the COST E24 workshop in Coimbra, Mai 2001

Nielsen LF (2001b) Lifetime and residual strength of wood subjected to various load variations. Contribution to the COST E24 workshop on 'Reliability based design of timber structures' held in Copenhagen, Denmark, October 19-20

Nielsen LF (2002a) On the influence of crack closure on strength estimates of wood. Paper presented at the COST E24 workshop on 'Reliability based design of timber structures' held in Zürich, Switzerland, October 10-11

Nielsen LF (2002b) Models for damage accumulation in wood. In: Casciati F (ed) Proceedings 3rd World Conference on Structural Control, held in Como, Italy, 7-12 April 2002, Dept. Struct. Mech., UnIversity of Pavia

Nielsen LF (2003) http://www.byg.dtu.dk/publicering/software_d. htm

Svensson S, Thelandersson S, Larsen HJ (1999) Reliability of timber structures under long term loads. Materials and Structures 32:755-760

Stang BD, Svensson S, Sørensen JD (2002) Effect of load duration on timber structures in Denmark. Paper presented at the COST-E24 workshop on 'Reliability based design of timber structures' held in Como, Italy, April 11-12 